Japanese Research in Business History 2005 | 22

\title{
The Development of Financial Restructuring in Japan, Making Use of the Assumption Company Strategy
}

Five Default Examples in the Kansai Region in the Early 20th Century

Isao OGAWA

Shiga University

7 HIS PAPER does not deal with restructuring carried out as a result of a firm's profit-and-loss situation, which may include

1 personnel retrenchment and cost reductions. It is concerned, rather, with restructuring in a financial sense. The author's attention will therefore be directed toward the actions that a financially troubled firm, that is finding it difficult to repay the interest and principal on its debts, may take in order to adjust its assets, liabilities and capital appropriately to enable it to survive. Naturally enough, a firm in this situation will have inflated the value of its assets and have incurred a large volume of liabilities, compared to what is an appropriate level, and as a result its capital will be either insufficient, or negative. The main theme of this paper is that of debt restructuring, of how - particularly in view of the necessity for difficult negotiations with creditor groups -the firm can reduce its burgeoning liabilities to an acceptable level.

When the symptoms are less than critical, measures are often adopted whereby the firm negotiates with its stakeholders and sells off idle assets, reduces its liabilities, and increases its capital, while retaining its corporate status. However, when the symptoms are truly severe, and an 
accommodation with stakeholders difficult to achieve, major surgical intervention becomes necessary. The largest-scale example of this type of restructuring in Japan was the division and privatization of Japanese National Railways (JNR), carried out in April 1987. In this case, the main company, JNR, which was no longer able to survive, was dissolved, and 7 newly-established joint-stock railway companies (JR) took over JNR's operations on a selective basis. In short, the reconstruction of the financially troubled JNR was effectively secured through a financial operation by which the new company accepted, in a limited and selective fashion, the goodwill, assets and liabilities of the original company. We refer to the 'new' company here as the 'assumption company', signifying a company newly established with the specific objective of taking over the assets (valuable or not, and including the goodwill), and all or a selected proportion of the liabilities of a financially-distressed firm that has reached a stage where restructuring is necessary. The JR companies were the assumption companies in the JNR case.

I shall hereafter refer to this type of restructuring - where there is a transfer of corporate status from one firm to another - as 'financial reorganization.' This paper will focus on this type of reorganization in prewar Japan, and by looking at 5 cases in the early 20th century in the Kansai region - then a major economic center - will consider the questions of from what time and by what sort of individuals it was carried out, how the process was initiated and how it was put into effect so as to achieve the reconstruction of enterprises and financial institutions. One person who enters the stage in nearly all these cases, either as a central figure or as a supporting actor in the process of financial reorganization, is the young businessman Naoharu Kataoka ${ }^{2}$, whose Diet speech in 1927 as Minister of Finance was to trigger the financial crisis in the spring of that year. One reason for the present author's particular interest in these cases is that he has much in common

1. For a general discussion of the privatization of JNR, see Tatsujiro Ishikawa and Mitsuhide Imashiro, The Privatization of Japanese National Railways: Railway Management, Market and Policy, London, The Athlone Press, 1998

2. For the career of Masaharu Kataoka see the English-language version of the Nippon Life Insurance Company's 100-year History: Mariko Tatsuki, Takao Shiba and Takau Yoneyama, The 100-Year History of Nippon Life: Its Growth and Socioeconomic Setting 1889-1989, Tokyo, Japan Business History Institute, 1991, pp. 23-24. 
with Kataoka in both the area and in the enterprises which saw his early ventures as a businessman. As a result of this analysis, the author feels that Kataoka can be regarded as one of the pioneers in Japan of financial reorganization using the assumption company strategy.

THE REORGANIZATION OF THE CHŪRITSU BANK, AND ITS DESCENDANT FIRMS

The Chūritsu Bank was established in Osaka in July 1894 by a group of influential capitalists, headed by the raw cotton merchant Jisuke Okahashi $^{3}$. The Chūritsu Bank had the distinction of being the first Japanese bank to carry out financing in Japan's colonies - in this case Taiwan - and also as a bank which in the very early period was involved in various types of financial restructuring.

The Chüritsu Bank was established to provide financing to the cotton industry, with raw cotton and cotton yarn (held in its collateral goods warehouses) as collateral. However, this practice of operating both as banker and warehouser did not go smoothly. In June 1895 the bank forayed into Taiwan - which Japan had obtained as a colony as a result of the Sino-Japanese War and now occupied - and established in Keelung the first representative office of a Japanese bank on the island ${ }^{4}$. Understandably enough, this decision to venture into banking in a colony, where the financial environment was completely different, was one accompanied by a considerable degree of risk. The Chûritsu Bank picked out a few ambitious employees and sent them off into this new territory.

It seems likely that among the major participants in the process by which the Nippon Chüritsu Bank acquired extensive holdings of real estate in Taiwan was Takaroku Yamanari, who accompanied the General Manager Tsunekuni Mihara to Taiwan, took up the post of Manager of the Keelung Branch, and contributed greatly to the business success of that Branch. The evidence for this assumption is that Yamanari the directors of the Bank placed great confidence in Yamanari, who was an

3. For the career of Jisuke Okahashi see ibid. pp. 48-49.

4. For colonial financing in Taiwan, see Masaaki Takashima, "Taiwan ni okeru shokuminchi kinyū no tenkai to sanjū-yon ginkō" [Colonial financing in Taiwan and the 34th Bank], in Senzō Hidemura et al., eds., Kindai keizai no rekishiteki kiban [The historical foundations of the modern economy], Tokyo, Minerva Shobō, 1977. 
extremely adaptable policy-maker, researching deeply into the economic conditions of Taiwan - so different from those of Japan proper - and (at least on the surface) had an outstanding business record. He was keenly interested in land, and was later to be involved in the establishment of a large number of landholding enterprises. Yamanari moved to the Bank of Taiwan, which had been established shortly after this in 1899, and having served successively as Manager of the Bank of Taiwan's Osaka Branch and Tokyo Representative Office, moved again, this time to become President of the Tōyō Sugar Refining Company. Tsunekuni Mihara, whose experience as Deputy Director of the Ministry of Finance Deposit Bureau and Budget Officer in the Bank of Japan had led to his appointment General Manager of the Nippon Chüritsu Bank in July 1897, also left, to become Chief Appraisal Officer at the newlyestablished Nippon Kangyō Bank. He was later to leave the banking field and turn his hand to mining, purchasing and operating gold mines in Miyagi Prefecture.

In order to insure against the risks of engaging in this new venture in Taiwan, the Chūritsu Bank set about a three-stage reorganization plan. First, having received approval in October 1894, the Bank hived off its warehousing business and formed Nippon Warehouse, with Jisuke Okahashi as Representative Promoter, and with his close associate Sukesaburō Hirose, and Naoharu Kataoka and others associated with the Chûritsu Bank as Promoters 5 . In February 1902 Sumitomo purchased the Dōtonbori, Ajikawa and Tenma warehouses of Nippon Warehouse, which ceased trading 6 .

The second stage was the disposal of nonperforming assets. At the time of the merger of the Nippon Chüritsu Bank with the 34th Bank and the Nippon Kyōdō Bank, with which Jisuke Okahashi was closely involved, the partners in the proposed merger had raised difficulties over the Chüritsu Bank's hugely valuable holdings of land.

The measure adopted was to establish an assumption company, Chūritsu Kigyō, to take over the 1.32 million square meters that the Nippon Chūritsu Bank owned in Taiwan. Chūritsu Kigyō was a pure real-estate company, engaged in the buying and selling, leasing and

5. Nippon sōko setsuritsu kankei shorui, [Documents concerning the establishment of Nippon Warehouse], 1894, held by Osaka Prefecture.

6. Sumitomo sōko 60-nenshi [60-year history of Sumitomo Warehouse], 1960, p.34. 
renting of real estate in the island of Taiwan. Former shareholders of the Nippon Chüritsu Bank became Directors of this new company.

Chūbei Itō (the founder of the trading companies C.Itoh and the Marubeni Corporation), who was a shareholder of the Nippon Chūritsu Bank, recorded in his Handbook, which also served as a record of his assets, that '(this) was an investment in common property in Taiwan', and added a note that his shares in the Nippon Chüritsu Bank had been compulsorily 'converted ${ }^{7}$.' He regarded these 10 shares as of doubtful value as assets, and excluded them from his 1898 annual inventory. In May 1910 Chūritsu Kigyō, a major landlord in Keelung, merged with a local Taiwanese firm, Taiwan Housing and formed Taiwan Land and Housing, with a capital of $¥ 1.5$ million. As of March 1911, shortly after the merger, Taiwan Land and Housing owned 354,000 square meters of land in Keelung, and 1,797,000 square meters elsewhere, making a total of $2,151,000$ square meters, with a value of $¥ 418,000$. The great majority of the landholdings elsewhere, in the suburbs, were inherited from Chūritsu Kigyō, which had been a major landlord in Keelung.

\section{THE REORGANIZATION OF THE KAYŌ RAILWAY AND \\ THE ESTABLISHMENT OF THE KANAN RAILWAY}

In 1891 a group of wealthy individuals from Tondabayashi made an application for approval of the establishment of the Kayō Railway (now the Nagano Line of the Kintetsu Railway), which was to be a local horse-drawn railway, running along the Köya Highway between Kashiwara and Kawachi Nagano in the south of Osaka Prefecture. The plans were then changed to a steam railway, and on July 21, 1893 an application was made for its construction between Kashiwara and Mikkaichi. A provisional license was received in October 1895, and final approval on February 4, 1896. The line between Kashiwara and Furuichi opened on March 24, 1898, and between Furuichi and Tondabayashi on April 14 the following year.

Jisuke Okahashi - whom we have already encountered in connection with the Chüritsu Bank - together with many of his partners, were also involved as shareholders in the Kayō Railway. Okahashi himself

7. Chūbei Itō, Tenohira-chō, [Handbook], 1899, held in Chūbei Itō family records. 
recorded: 'I felt very strongly that the development of transport in the southern part of the Kawachi district was underdeveloped, so I proposed the setting-up of the Kayō Railway, and managed to bring it to fruition ${ }^{8}$.' In 1890, the Nippon Life Insurance Company, for whom Okahashi also acted as internal auditor, had designated the Tondabayashi Bank - which had close connections with the promoters of the Kayō Railway - as a representative branch. From this relationship we can assume that funding for the Kayo Railway came not only from the 34th Bank - which is known to be the case - but also from the Nippon Kyōdō Bank, which had a close relationship with Nippon Life.

After the Sino-Japanese War, the boom in new company formation became overheated, business activity went into decline, and the managements of many newly-formed businesses found themselves in difficulties. In 1898, shortly after its foundation, the survival of the Kayō Railway as a corporate entity was problematic; it had accumulated debts of $¥ 152,000$, and had only partially started operations. Kataoka Naoharu, Vice-President of Nippon Life, recalls that in April 1899 'the Kayō Railway fell into management problems as a result of poor business performance. My friends and acquaintances pressed me strongly to take on the task of reorganizing the company. So, in addition to my managerial responsibilities in Nippon Life, I became involved in the railway business for the first time. Round about this time, for similar reasons, I also took charge of the financial reorganization of the Kiwa Railway ${ }^{9}$.' From the nearness in time of the General Meeting that established the Kanan Railway (January 23, 1899), and the General Meetings of the 34th Bank, the Nippon Kyōdo Bank and the Nippon Chüritsu Bank that approved their merger, we can infer that there was a connection between the reorganization of the Kayō Railway and the merger of the three banks. We can surmise also that Kataoka's involvement with the Kiwa Railway and the Sangū Railway, which started at about the same time, was linked to the thorough reexamination of their assets that accompanied the merger of the three

8. Jisuke Okahashi, Jigyō keireki [My business career], 1899, held in Okahashi family records.

9. Naoharu Kataoka, Kaisōroku [Recollections], Kyoto, Hyakushikyo Bunko, 1933, p.246. 
banks, in a similar fashion to that which took place with Chūritsu Kigyō, referred to above.

After Kataoka had carried out a thorough investigation into the situation of the Kayō Railway, his conclusions concerning it reorganization were as follows:

'The value of the shares of the Kayo Railway has fallen to below half their paid-in value, so the company cannot be restructured by the usual means used for corporate reorganization, such as a simple increase in capital. The only possible method of restructuring would seem to be the following: (a) A new railway company is formed using the same lines and the same layout as the Kayō Railway; (b) the promoters of the new company apply to the railway authorities for approval of the railroad construction proposal; (c) An Emergency General Meeting of the Kayō Railway is held, to pass a resolution putting the Company into voluntary dissolution when the new company receives approval, this resolution being signed by the shareholders and submitted to the authorities; (d) the Kayō Railway and the new company sign a sales contract under which the new company purchases all Kayō's assets; (e) the sellingprice is set below the book value of the Kayō Railway, at the present value of Kayō's debts; (f) as a result of this the Kayō Railway writes off a sum equivalent to its capital; ( $g$ ) when the new company receives approval, all the assets of the Kayô Railway are sold to it. ${ }^{10}$,

First, on November 29, 1898, in accordance with Kataoka's prescription, the Kayō Railway held an Emergency General Meeting which decided on dissolution. On December 1, 1898 a provisional license was issued to a new company, the Kanan Railway. On January 21, 1899 the Kanan Railway signed a contract agreeing to purchase all the assets of the Kayo Railway for a sum equal to the total of the latter's debts. On January 23, 1899 the Inaugural General Meeting of the Kanan Railway was held and the company was established, with 6,000 shares and a total capital of $¥ 30,000$. Kataoka and Sukesaburō Hirose

10. Kanan Tetsudō [Kanan Railway], Dai ikkai hōkoku [First report], Osaka, Kanan Tetsudō, September 1899. 
took up posts as Counsel to the company.

Nine Kayō Railway creditors - including the major creditor, the 34th Bank - who were owed a total of $¥ 152,000$, were allocated 3,046 Kanan Railway shares with a face value of $¥ 50$ each. The 34th Bank and other creditors did not pay for these shares, but each wrote off Kayō Railway debt equivalent to the value of the shares they received. In this way the creditors were able to amortize their unrecoverable loans, and in return receive shares in a company now reborn with no debt hanging over it. The final result was that $¥ 228,000$ of Kayō Railway debt was amortized, and that the past deficits had been wiped out the shareholders of the old company by means of a sum equivalent to the capital originally put up by the shareholders in the old company. This technique of exchanging debt for shares - known as a Debt Equity Swap (DES) - is widely used even today.

According to the Kanan Railway stock subscription ledger, major stockholders with more than 150 shares included the 34th Bank (600 shares), the Nippon Kyōdō Bank (400), Jisuke Okahashi (400) Kahei Murakami (400), and the Yūgyo Bank (200). A large number of the directors of the banks involved also invested as individuals.

On April 7, 1899 the Kanan Railway received its license, and on May 10th the Kayō Railway was wound up, selling all its railway undertaking to the Kanan Railway for $¥ 228,190$. By this passing of the undertaking between the old and new companies, the Kayō Railway was able to reduce its fixed assets and liabilities, and be reborn as the Kanan Railway, with the potential to keep its income and expenditure in balance.

The rehabilitation process for the Kanan Railway thereafter was by no means easy. The 34th Bank, which had successively taken over the Nippon Kyōdō Bank and the Yūgyo Bank and thus inherited their shares in the Kanan Railway, was aware that they were virtually worthless assets, and had already written their book value down to $10 \%$ of their face value, but in 1904 it took the final step of writing off completely all its 1506 shares in the Kanan Railway, with a face value of $¥ 75,300$ and a book value of $¥ 7,530$. This was in accordance with the standard method of dealing with this type of passive shareholdings - namely to write down their book value as far as possible, and then find a suitable opportunity to write them off altogether, or find a party willing to take 
them over. After the 34th Bank had disposed of its large holding of fully amortized shares in the Kanan Railway, the person who appeared as the railways largest shareholder was Kichibei Noda. Noda was a close partner of Okahashi, and had served as the first Director and General Manager of the 34th Bank. His policy concerning shareholding was once he had bought shares never to sell them off, but to share in the company's destiny come what may; one might say that his watchword was 'super-long-term' or 'eternal' shareholding. It is likely that it was this philosophy that impelled him to pick up shares in the Kanan Railway.

THE REORGANIZATION OF THE KITAMURA BANK AND

THE ESTABLISHMENT OF IZUO LAND

The Kitamura Bank was a small privately-owned bank, established in April 1895 with a capital of $¥ 50,000$. Its head office was located in Senboku County, Osaka Prefecture, with a branch in Nishi Ward, Osaka City. The owner of the bank, Rokuemon Kitamura, was a major landlord in Senboku County. At the time of the 1901 financial panic, a rumor that Kitamura had made a huge purchase of low-priced shares, including those of the struggling Koya Railway caused a run on the Kitamura Bank, which had to suspend payments to its depositors. Even in the pre-panic financial circumstances of January 1899 had outstanding debts of $¥ 288,000$, against a capital of $¥ 50,000$ and deposits of $¥ 258,000$. Included in its assets was a great deal of real estate, and as much as $¥ 43,000$ in shares. Overall, it was in a fundamentally unsound condition.

Many of the bank's depositors were tenant farmers in the Izuo Shinden district, and negotiations were very difficult, involving as they did landlord-tenant antipathy. Among the bank's creditors were several banks, including the Osaka Nōkō Bank, and the powerful Naniwa Bank, which was owed $¥ 190,000$. The interests of the various banks were in conflict with one another, and with the real danger of a chain reaction of bankruptcies occurring, the courts were about to become involved in cases for the reclamation of the Kitamura Bank's debts.

One of the largest creditors, the Osaka Nōkō Bank, was depositholder for the public funds of Osaka Prefecture, jointly with the 
Kitamura Bank, and the collapse of the latter meant that the Osaka Nōkō Bank would have to recompense the Prefecture to the tune of some $¥ 100,000$, equivalent to one-fifth of its capital. The shock to the bank was considerable, and in January 1904, Shōjirō Hirose of the Banking Bureau of the Ministry of Finance (second son of Sukesaburō Hirose, referred to above in connection with the Chûritsu Bank) was appointed Managing Director of the Osaka Nōkō Bank, with the task of finding a way out of this difficult situation.

It would have been possible to settle the affairs of the Kitamura Bank and pay off all its debts by selling the real estate that the bank's owner held in Izuo Shinden. However this considerable area $(1,238,000$ square meters) of land in Izuo Shinden was being cultivated by tenant farmers, who were also depositors in the Kitamura Bank, so there was little prospect of converting it quickly into cash. The problem was brilliantly solved by Jūtarō Matsumoto (nicknamed 'Osaka's Eichi Shibusawa), President of one of Osaka's major financial institutions, the 130th Bank. Around this time Matsumoto had demonstrated his remarkable skills by such feats as successfully mediating the merger between the Kansai Railway and the Osaka Railway, and had made a name for himself in the Osaka business world as a genius at finding smooth solutions to critical financial problems. $\mathrm{He}$ is also credited with having been the first banker in Japan, at the time of the issue of the Hankaku Railway's corporate bonds, to arrange for a financial institution to underwrite the risks involved in issuing corporate bonds. The 130th Bank itself was not one of the Kitamura Bank's major creditors, so it would appear that Matsumoto was in a neutral position when he took on this task. Matsumoto's proposed solution was the securitization of real estate - for the Bank's creditors to set up a new company, using as capital sums equal in value to their outstanding loans to the Bank, and for this company to buy the land in Izuo Shinden.

In the end the stratagem adopted to clear the Kitamura Bank's total debt of $¥ 1,340,000$ was as follows. Small depositors received partial repayment of their deposits, and special payments were also made to certain other creditors such as Tokyo Fire Insurance. The 1,238,000 square meter tract of land in Izuo Shinden, which was difficult to convert into cash, was to be purchased for a total of $¥ 75,000$ by major creditors such as the Naniwa Bank and the Awa Commercial Bank. In 
order to liquidate the Kitamura Bank's debt, this land was securitized, and the creditor banks received shares in the newly-created company, Izuo Land. Of the firm’s $¥ 750,000$ capital, the Naniwa Bank put up $¥ 190,000$, other banks $¥ 300,000$, and large depositors $¥ 250,000$. Among the shareholders there were a considerable number from the banking world beyond the Kansai region, revealing the extent of the area from which the Kitamura Bank had borrowed funds. Creditors meetings were held under the auspices of the Osaka District Court, and a variety of other negotiations took place repeatedly, but there were severe conflicts of interest between the various creditors, and no solution seemed in sight. Public auctions were held of some of the Bank's collateral, but the sums realized fell far short of their target, and a declaration of bankruptcy was presented. It appeared for a time that there was virtually no hope for a successful resolution of the Kitamura Bank problem. However, Yoshikichi Shimizu of the Osaka Shimizu Bank, later to become President of Izuo Land, rushed around from one group of creditors to another in search of a compromise, and a solution was finally found. Shares were also to be issued to the depositors in the Bank - mainly tenant farmers in Izuo Shinden - and by increasing the founding capital to $¥ 950,000$ it was possible to obtain the consent of creditors accounting for three-quarters of the outstanding debt to a bankruptcy agreement, avoiding the necessity for bankruptcy. The declaration of bankruptcy was withdrawn, and in December 1903, Izuo Land was finally established with over 900 shareholders.

At first, though the real estate held by Izuo Land was located close to an urban area, transport connections were poor, and the sale of plots went very slowly. However, speculators like Momosuke Fukuzawa, the adopted son of Yukichi Fukuzawa, foresaw the rapid progress of urbanization and a consequent rise in land prices, and saw in the shares of Izuo Land an alternative to the troublesome process of investing directly in real estate. This led to an increase in the demand for the shares, and the banks that had been holding the Kitamura Bank's bad debt were now able to sell their shares in Izuo Land, and to some extent recover their losses.

As the construction of the nearby Port of Osaka progressed, and the tramway system was extended to the district, Izuo Land's holdings of real estate were suddenly in a prime location. As more housing and 
factories were constructed the price of land gradually increased, and after 1910 there was a sharp rise in the number of plots being sold. As a result, the shares, with a par value of $¥ 20$, averaged $¥ 109$ during this period, hitting a peak of $¥ 170$ in 1916 , a quite remarkable rise for the period, and Izuo Land was extolled as 'the first among the hundred or more real estate firms in the Kansai region' and 'the pick of the real estate companies.' Finally, in 1930, Izuo Land, having achieved its destiny, and written a brilliant page in the history of the real estate business in Japan, closed its doors, leaving us with one of the few examples of the successful use of the 'land company method' of securitization to reorganize a company facing financial collapse.

\section{THE REORGANIZATION OF SAIGA \& CO. AND}

THE ESTABLISHMENT OF NIPPON KŌGYŌ

Saiga \& Co. ${ }^{11}$ was a privately-owned company established in 1896 by Tōkichi Saiga, who rose from the status of a humble electrical technician to become what some called 'the.electrical king.' For electric lighting and electric railway projects from Hokkaido in the north to Okinawa in the south, the company not only sold equipment and acted as construction contractor for, but also set up companies, offered shares for subscription, and even took up unsubscribed-for shares and involved itself in management. As a result, according to the 'List of Affiliated Companies' based on a survey dated July 31, 1913, the electrical companies forming the 'Saiga Kingdom', in which either Tōkichi Saiga or executives of Saiga \& Co. were either major shareholders or directors, numbered 80 in total - 39 in operation, 41 not yet in operation - with a total capital of $¥ 29,385,000$. Broken down by area of business activity, 13 of these 80 firms were engaged in hydroelectric power generation, 45 in thermal power generation, 5 in both electric lighting and electric tramways, 6 in both electric tramways and light railways, 1 in the manufacture of electrical machinery, 2 in electric tramways and 8 in light railways. If we add to these the 84 companies still in the

11. For detail on Saiga and Co. see Masafumi Miki, Kindai nihon no chiiki kōtsū taikei [The regional transport system in modern Japan], Tokyo, Taimeidō, 1999, Chapter 7. 
planning stages (73 in electric lighting, 5 in electric tramways, 6 in light railways) with their capital of $¥ 15,579$, the 'Saiga Kingdom' encompassed 164 companies with a total capital of $¥ 44,964,000$, accounting for one-seventh of the whole of Japan's electrical industry ${ }^{12}$.

However, Saiga \& Co., which stood at the pinnacle of this structure of 164 companies, was a purely individual enterprise, lacking corporate status, with financial resources far short of those needed to support operations on this scale. On the one hand they would issue bills payable to their suppliers such as Furukawa \& Co., Mitsui \& Co., and Okura \& Co., while on the other, they would accept shares in the electrical companies who were their customers to cover a large proportion of their accounts receivable and contract fees. They would then use these shares as collateral to borrow funds from banks and elsewhere with which to set up the next electrical company, in a precarious 'keep pedaling or you'll fall off' type of operation. Tōkichi Saiga himself was an intrepid expand-or-bust type of character, sadly lacking in risk management ability, so his judgment of danger - whether to go ahead with founding a new company or to hold back - was extremely slipshod. And while on the one hand the company had in its employ a large number of talented electrical engineers who had graduated from the Imperial Universities, the management staff supporting Saiga, the owner, was very weak, consisting of two men - the General Manager, Giichirō Noda, and the Secretary, Yaichirō Honda. Partly because of the private character of the company, they adopted a policy of extreme secrecy, not even presenting business reports to the banks with which they had dealings.

Around this time, as a result of a fraudulent bill scandal involving Mitsui \& Co., the banks were extremely wary of company bills, and to compound matters, the banks were closed for three days for the funeral of the Meiji Emperor, so that cash remittances from the provinces were delayed. As a result, on September 16, 1912 one of Saiga's bills was dishonored, and the company had become insolvent. This event triggered revelations about the chaotic state of Saiga's management, and the company was forced to suspend operations. It had now turned into a major economic incident, adversely affecting, directly and indirectly,

12. Report to the shareholders of Nippon Kōgyō, Saiga denki shōkai no seiri tenmatsu [The story of restructuring Saiga \& Co.], Osaka, Nippon Kōgyō, September 1913, p.2. 
well over 100,000 individuals involved all over the country in Saiga's 164 affiliated companies as shareholders, creditors, suppliers of machinery or building materials or working on construction projects.

Matters having reached this stage, Tōkichi Saiga entrusted the entire disposition of the affair to Naoharu Kataoka of Nippon Life, and Bin Hiraga, President of the Fujimoto Bill-broker Bank. Bin Hiraga described the situation at the time as follows:

Since I had been doing business with them for some time, I was in favor of the Saiga rescue ... I went with Naoteru Kataoka to the Nippon Life Head Office, where we met Naoharu Kataoka and asked him to carry out the rescue. In those days insurance companies were the financial institutions best able to find funds for the financing of business, the insurance companies were my bank's best customers. Consequent on Naoharu Kataoka agreement to our request to help rescue Saiga, Nippon Life made a selection of reliable shares and bills from among those held by Saiga, and with these as collateral advanced a considerable amount of funds ${ }^{13}$.'

At the request of Naoharu Kataoka, now acting as unofficial receiver, Mototarō Ogino, head of the Osaka Branch of Furukawa \& Co., one of Saiga's main customers, spent three days and nights going through Saiga's financial records with a fine tooth comb. According to the balance sheet that he drew up, Saiga’s total assets came to $¥ 9,560,000$, and its total liabilities to $¥ 9,720,000$, giving a deficit of only $¥ 160,000$. However, Saiga \& Co. was a type of public works holding company, with many of its assets being high risk and virtually untradeable, including 587,000 shares in electric and tramway ventures which had either only just started operations, or had not yet done so. If these assets were to be revalued by marking them down to their market value, the asset deficiency would inevitably increase considerably.

The conclusion reached by Ogino after his examination of Saiga's books was that the company's insolvency was a result of the too rapid

13. 'Conversation with Bin Hiraga', in Kihachirō Shirota, Ōbayashi Yoshigorō den [Biography of Yoshigorō Ōbayashi], Osaka, Ōbayashi-gumi, 1940, p.271. 
expansion of its undertakings. He did not find any examples of the improper diversion of funds to extraneous activities out side the electrical sector, or into speculative ventures. This made Kataoka very sympathetic toward Saiga, and he acceded to Saiga's earnest request, and decided to put all his efforts into the reorganization of the company. Talking to a newspaper reporter at the time, Kataoka said: 'There is no personal ambition behind my acceptance of the role of unofficial receiver. Tökichi Saiga came to me in a manly fashion, saying that he was willing to hand over all his personal fortune. This was the only thing that impelled me to try to rescue the firm.'

The financial reorganization of Saiga \& Co., took place in a series of tentative stages, as follows. As a first step, Kataoka and his associates opened negotiations with Saiga's large business partners, Furukawa \& Co. and Ōkura \& Co., to persuade them initially to take over the whole of the 'Saiga Kingdom', and then proceed to reorganize it. He also planned to negotiate on a political level to persuade the Bank of Japan to provide the funds necessary as a first step to get the rescue plan under way. However, the Ōkura and Furukawa families, who ranked among the wealthiest in Japan, eventually refused to participate in this firststage reorganization plan. Saiga's business activities were so extensive, and the business relationships between the companies concerned so complex that they felt unable to get a grasp of the whole picture.

Kataoka's next step was to approach Seishū Iwashita, President of the Kitahama Bank, which was unusual among Japanese banks in that it had much of the character of an investment bank. Kataoka wanted to persuade Iwashita to have the Denki Trust, in whose establishment Iwashita had played a central role, take over all Saiga's business activities. The Denki Trust was a trust company set up at Iwashita's instigation, with the objective of combining electric lighting and light railway enterprises all over the country and forming a single large nationwide electrical trust. Unfortunately, however, immediately after setting up the Denki Trust Iwashita departed on a long trip overseas. The Denki Trust's actual investment record, however, was limited to the investment of $¥ 150,000$ in the Settsu Electric Light Company, with the remainder of its capital being on deposit with the Kitahama Bank. It therefore had plenty of funds at its disposal, and Kataoka persisted in his negotiations with the Trust for approaching half a year. At one time it 
appeared that the negotiations would bear fruit, but in the absence of their Chairman, the directors of the Denki Trust were unable to reconcile their conflicting interests, and this second reorganization plan also failed to bear fruit.

The third reorganization plan was for the establishment of an assumption company, with Saiga's unsecured lenders as its shareholders, to take over Saiga's affairs. At the end of 1912 Seishū Iwashita, President of the Kitahama Bank - Saiga's main bank - and Chairman of the Denki Trust, returned to Japan from his long trip overseas. In April 1913 Nippon Kōgyō was established, and assumed responsibility for all of Saiga's business. As a temporary measure Saiga's creditors converted their claims into Nippon Kōgyō shares with a face value of $¥ 2,000,000$ and corporate bonds to the value of $¥ 1,1000,000$. Among those accepting the $9 \%$ interest-bearing bonds, secured by the bank, were major creditors, including Nippon Life and Tokyo Marine Insurance.

The restructuring plan adopted by Nippon Kōgyō was to convert high-yielding debt into relatively low-yielding preferred stock and corporate bonds, thus reducing the interest burden. The plan also called for the dismissal of about one-third of Saiga's employees, reducing the number of retail outlets by half, and a similar $50 \%$ reduction in overall operating costs.

Starting in about February 1912, just when the third reorganization plan was gradually getting under way under the leadership of the Kitahama Bank, an Osaka newspaper, the Osaka Nichinichi Shinbun, started a long-running series of articles attacking Iwashita, President of the bank. For example, referring to the securities held by the Kitahama Bank the newspaper struck home with great accuracy at the Bank's weaknesses, commenting that 'it is likely that these include corporate bonds issued by the currently problem-ridden Nippon Kōgyō. It can be assumed that they are also holding shares that are virtually junk. It is also certain that they are hiding a large number of worthless Nippon Kōgyō stock, left over because they were undersubscribed, as their asset value is exceedingly dubious. Because the Kitahama Bank is holding so many worthless assets it is unable to make public the details of its holdings ${ }^{14}$.' The sources of some of the newspaper's information were

14. Ōsaka Nichinichi Shinbun, April 15, 1914. 
major shareholders in the Kitahama Bank. The information was no mere canard, based on speculation, but was extremely accurate, getting straight to the heart of the issue. As a result we can assume that many local banks who were some of the Kitahama Banks largest depositors took this news seriously, and hastened to withdraw their deposits. Partly, therefore, in consequence of its involvement with the Saiga reconstruction venture, April 1914 saw a run on the Kitahama Bank. Eventually, in June 1916 Nippon Kōgyō too was forced out of business, and all of the efforts to rescue Saiga and Co. had ended in failure.

\section{THE DAI NIPPON HOTEL}

In 1906 Nihei Nishimura, owner of a long-established hotel in Kyoto, planned to build a hotel on a 50,000 square meter plot of land in Nara. The detailed planning was carried out by Kingo Tatsuno and Yasushi Kataoka. Naoharu Kataoka, who had long been enthusiastic about the idea of hotel management, had the Kansai Railway, of which he was President, lend $¥ 50,000$ to the hotel as funds for the construction, and lent his wholehearted support.

In 1907 changes had to be made in the hotel construction scheme. In that year, with the Miyako Hotel in Kyoto as the nucleus, hotels in Ujiyamada, Yokkaichi and Arima merged to form the Dai Nippon Hotel, a major hotel trust. Further, in October of the same year the Kansai Railway was nationalized and the $¥ 102,687$ construction cost for the Nara hotel became the responsibility of the national government. As a result, a new contract was drawn up between the Dai Nippon Hotel and the Railway Agency of Japan, which as a result of nationalization now managed a unified trunk railroad network. It was agreed that the Railway Agency would construct the Nara Hotel, and lease it to the Dai Nippon Hotel, to whom it would entrust full responsibility for its management.

In February 1909, based on the Mortgage Bond Trust Act of 1904, the Dai Nippon Hotel took out a mortgage bond with the Industrial Bank of Japan (IBJ) to a total value of $¥ 175,000$, in order to finance the expansion of its hotel chain. The whole bond was subscribed for by third parties, with a period of five years and an interest rate of $8.5 \%$, the Dai Nippon Hotel's real estate being used as security. On the reverse of 
the bonds it is clearly stated that they were subscribed for in full by the three life insurance companies Nippon Life, Teikoku Life and Aikoku Life, and Kichibe Murai, who had switched to banking from his former career as proprietor of a private-sector tobacco company. When Kataoka had returned from Europe in 1906 he had asked the insurance industry for support in establishing western-style hotels, and it was he who was the driving force behind the formation of this group of subscribers.

At the General Meeting of Nippon Life in February 1910, Kataoka emphasized the significance of the acceptance by the company of the Dai Nippon Hotel bonds. "The hotel business is vital for Japan's development at the present time. While the number of foreigners coming to Japan is increasing year by year, it is unfortunate that there is insufficient provision of western-style accommodations designed for foreigners' use. The Government too is discussing measures for the protection of the hotel industry. Taking all these circumstances into account, we acceded to the Dai Nippon Hotel's request that we furnish funds, judging it to be in the national interest. However, to ensure that we are not saddled with irrecoverable debt, we have taken all of the hotel firm's assets as security, and using the secured mortgage bond instrument have provided $¥ 50,000$ in funds, in concert with Teikoku Life and Aikoku Life."

However, the Dai Nippon Hotel's aggressive plans for the expansion of their hotel chain backfired; business was not good, and they became unable to repay the principal and interest on the bonds in time. Suetomo Nishimura, Finance Director of Nippon Life, was dispatched to the Dai Nippon Hotel as Accounting Manager, and reported regularly to Kataoka on the results of his inspections of the finances of the firm. The profits earned by the flagship hotel in Kyoto, which was doing good business, were outweighed by the losses incurred by the other hotels in the chain, in Nara, Ise and Arima. On the basis of these reports, Kataoka, representing the three insurance companies, demanded that the Dai Nippon Hotel carry out a restructuring. The firm's President, Nihei Nishimura, attempted a recapitalization by putting his own shareholdings up for sale, but was unable to find a buyer. Nor did cost reduction measures at the various hotels produce the expected results, and in the end the bondholders announced that, failing a repayment of 
$¥ 70,000$ by October 1912 , they would institute official foreclosure proceeding with respect to the real estate that they held as security. During this period a reorganization plan to convert the mortgage bonds into low-interest corporate bonds was mooted by an influential Kyoto figure, Kotetsu Hamaoka, but this failed to obtain the agreement of the bondholders.

The bondholders had no alternative to foreclose, and starting in December 1913, the property held as security was offered at a series of auctions. Although the reserve price was successively lowered, no purchaser was to be found, and there was a fear that the hotels could end up being sold off for a ridiculously low price to someone entirely unsuited to the business of hotel management. After discussions among the bondholders they decided on the step of 'self-foreclosure', and the bondholders themselves purchased the properties for $¥ 210,000$, in the name of Tokitarō Yoshii, a member of the staff of Nippon Life's real estate division.

During this period, various incidents occurred involving the reorganization plan, including the seizure of moveable assets by unsecured bondholders. Eventually, in April 1915 the firm was reconstructed as the Miyako Hotel, with the three insurance companies as shareholders. This was effected through a debt-equity swap (DES) of the mortgage bonds for shares in the new company. Kataoka himself became President of the new company, and Tsutomu Kishida, managing director of the Kyoto Electric Railway was selected as managing director, with the Board of Directors being dominated by representatives of the former bondholders. Fall that year saw the magnificent Coronation ceremonies of the Taishō Emperor, and the Miyako Hotel was filled with dignitaries attending 'the event of the century.' It was an appropriately glittering start for the new company ${ }^{15}$.

\section{CONCLUSION}

Only 5 examples of reorganization have been cited in this paper, but the firms involved are varied in type, with the first and third examples

15. Keitarō Tokunaga, Miyako hoteru 100-nenshi [The hundred-year history of the Miyako Hotel], Kyoto, Miyako Hotel, 1989, pp.44-52. 
being banks, the second a railway, the fourth an electrical trading firm, and the fifth a hotel group. The stakeholders who imposed the restructuring also fall into several categories: in the first case, shareholders; in the second, the banks providing finance; in the third, the bank's major creditors; in the fourth, the trading firm's creditors, and finally, the mortgageholders of the hotel group. Apart from Case 3, Naoharu Kataoka was involved in some capacity in all these incidents, and we can see between the cases some evidence of a passing-on of accumulated experience of reorganization. In particular, between Chûritsu Kigyō in the first case, and the railway reorganization in the second, we can surely see a process of debt disposal carried out in a simultaneous co-ordinated fashion among a group of capitalists.

The group of capitalists led by Jisuke Okahashi, and known as the 'Okahashi group'16, had repeatedly undertaken this type of reorganization, making use of assumption companies. As a result, there had developed among the members of the group a body of shared wisdom - a 'common culture', as it were - concerning methods for the disposal of non-performing debts.

Chūbei Itō too, who was like Sukesaburō Hirose an 'Ōmi merchant', and who had at Hirose's introduction invested in some of the Okahashi group's enterprises, had sent men of manager level to attend the shareholders meetings of the Nippon Chūritsu Bank. He is likely, therefore, to have had a fairly accurate understanding of the economic significance of the establishment of Chūritsu Kigyō. His awareness of the status of these common assets held by the shareholder group can be seen in the fact that he held no great expectations for these shares, which he had had little choice but to accept, and coolly wrote them off when he carried out his inventory for that year. In the same way, rather than taking five years to amortize the shares that the 34th Bank had accepted as part of the debt-equity swap involving the Kanan Railway the Bank wrote them off extremely expeditiously. We can assume that the 'culture' that developed in the 'Okahashi group' and elsewhere

16. Concerning the character of the 'Okahashi group', see Isao Ogawa, "Nippon seimei sōgyōsha jinmyaku to Hirose, Okahashi, Kataoka-ra no kyōdō tōshi kōdō" [The personal connections of the founders of Nippon Life, and the joint investment activities of Hirose, Okahashi and Kataoka], in Yōtarō Sakudō, ed., Kindai Ōsaka no kigyōsha katsudō [Entrepreneurial activity in modern Osaka] (Kyoto, Shibunkaku Shuppan, 1997). 
through the experience of cases 1 . and 2. above, of using an assumption company to reorganize a financially troubled firm, spread to other railway companies and the enterprises of other capitalists ${ }^{17}$.

17. Other examples of the use of an assumption company (or the ideas behind it) include the cases of the Ōta Railway, the Kibe Railway, the Zusō Railway, the Kōya Railway, the Hirobe Bank, and the Tokyo Watanabe Bank. Space did not permit their inclusion in this paper, but the reader is referred to Isao Ogawa, Kigyo hatan to kin' $y \bar{u}$ hatan - fu no rensa to risuku zōfuku no mekanizumu [Enterprise failure and financial failure - the mechanism of the negative knock-on effect and the amplification of risk] (Fukuoka, Kyushu University Press, 2002). 